Geopolitics, the Revolution in Military Affairs, and the Bush Doctrine

\title{
Simon Dalby
}

YCISS Working Paper Number 49

May 2008 


\title{
Geopolitics, the Revolution in Military Affairs, and the Bush Doctrine
}

\author{
Simon Dalby \\ Professor of Geography and Political Economy \\ Carleton University
}

YCISS Working Paper Number 49

May 2008

The YCISS Working Paper Series is designed to stimulate feedback from other experts in the field.

The series explores topical themes that reflect work being undertaken at the Centre. 
See, September the 11th changed the equation. It used to be that oceans would protect us, that we saw a threat, we didn't have to worry about it because there was two vast oceans. And we could pick and choose as to how we deal with the threat. That changed on September the 11th.

George W. Bush, April 2004

\section{GEOPOLITICS AND THE REVOLUTION IN MILITARY AFFAIRS}

Geopolitics is about the political organization of space, and about how this is conceived, represented, and used in political discussion. The term refers to power at the largest of scales and simultaneously to the geographical arrangements of that power. It is linked directly to European modes of conceiving the world as a whole and then discussing how it is divided and ruled by many political organizations (Agnew 2003). Inevitably it has a military dimension because political power is never entirely divorced from matters of coercion and violence. Strategy and political power have unavoidable geographical dimensions, but ones that are not always well understood by either politicians or the publics who advocate the use of military force.

But first and foremost geopolitics is about the initial specification of the world in ways that subsequently facilitate policy in the world presented in that particular manner. Thus places with certain attributes can be presented as requiring certain policies. Modes of conduct are tied to these prior contextualisations in much policy discourse, a simple but obvious point that is so unremarkable as to frequently pass without comment. In the aftermath of September 11th 2001 the world was remapped in the political discourses of the war on terror (Dalby 2003). Initially it was unclear what the appropriate geography was to specify what had happened; '9/11,' a temporal designation rather than a geographical one, is still used to specify the new circumstances. But remapped the world was, into the categories of the Bush doctrine and its 'global war on terror'.

The Revolution in Military Affairs (RMA) is a label attached to discussions of the modernization of the U.S. military particularly in the last couple of decades, but has implications for other military forces too (Sloan 2002). The term is used loosely to refer both to technological innovations in weapon systems, and in particular the important changes wrought by computer technologies and communication systems. Most obvious in the "smart" weapons publicly revealed in the 1991 Gulf war, the technological innovations are supported by global positioning navigation systems and numerous communications technologies that enhance command systems and situational awareness on the part of commanders. Remote sensors and computer tracking of numerous targets supposedly allow sophisticated combat operations to out maneuver foes and destroy opposition targets relatively easily with few casualties. This requires a reorganization of armed forces with large tank and infantry divisions broken into smaller units to be more flexible and capable of moving much faster over long distances. In the phrase usually used by Donald Rumsfeld (2002) when he was 
American Defense Secretary, the RMA required nothing less than the 'transformation' of the American military. Not least is the requirement that the various services have much greater capabilities of working together in 'joint' operations, and have that capability literally anywhere on earth.

But military innovations are not new; historical analogies with contemporary developments are always tempting, but need to be addressed cautiously if appropriate lessons are to be drawn for present discussions (Boot 2006). One could start with a discussion of Alexander the Great and suggest that his father Phillip, king of Macedonia, had initiated a revolution in military affairs by perfecting a combined arms military machine, effectively linking phalanx, mobile infantry, and cavalry assault troops together in an innovative arrangement. His son Alexander took this military machine and defeated all comers in the ancient world in a military campaign that historians still consider with awe. The destruction of the Persian empire of Darius III dramatically changed the political arrangements of his time and did so by the application of the superior military capabilities of a relatively small force and the shock effect of rapid mobility.

Given the rapid changes in technology and political power in the last few decades the argument in this paper is in part that the RMA should not be divorced from considerations of geopolitics. In particular how military power uses and dominates spaces, both terrestrial, and now too in earth orbits outside the atmosphere, has become linked to the discussion of geopolitics, the geography of danger, and what kind of world order is being secured by these new high technology forces. How a geopolitical environment is understood by decision makers is key to planning and strategy; the designation of the 'global war on terror' as global well before the phrase morphed into 'the long war' matters because literally the whole planet is now seen as at least a potential battle space.

Combined with the technology of television cameras, and the frequent use of 'successful' hits by precision guided weapons as part of military and political briefings, one crucial question is whether the RMA has changed politics at the largest scale, and if so how this is understood by policymakers and politicians in many places. Beier (2006) argues that the framing and selection of targets has changed the social depth of warfare; enlarging the potential participants in warfare, not least because 'surgical strikes' with precision guided weapons supposedly reduces collateral damage, and hence allows their use where previous technologies would not have been employed. This paper suggests that this is also a matter of the geopolitical framing, of the representation of the world as a military arena at the largest scale which is implicitly, and sometimes explicitly, about a new understanding of geopolitics where war can now happen anywhere and anytime.

To make this argument the paper turns first to classical geopolitical thinking, nuclear strategy, and the theme of the containment of Soviet power in the Eurasian landmass. Then it looks to the military technologies of the RMA and their development in the latter stages of the cold war. Subsequently the paper examines the geopolitical logic of the 2006 Quadrennial Defense Review and the popular articulation of the Bush doctrine in Thomas Barnett's (2004, 2005) writing, with its explicit remapping of the world as the context for 
Dalby $\checkmark$ Geopolitics, the Revolution in Military Affairs, and the Bush Doctrine / 3

understanding the doctrine and the necessity of warfare in the Middle East and elsewhere. Much of the commentary on the war on terror, American foreign policy, the Bush doctrine, and Middle Eastern politics has bypassed these most basic geopolitical ideas that structure American strategy. Including these themes explicitly in the discussions matters not only for completeness, but because thinking about alternative formulations of security after the Bush doctrine requires, among other things, a coming to terms with its geopolitical categories.

\section{GEOPOLITICS AND NUCLEAR STRATEGY}

Much of the praise or blame for contemporary geopolitical thinking is attributed to British geographer Halford Mackinder and his much cited 1904 paper on the 'geographical pivot of history'. In his formulations he looked to central Asia as the key to world power, arguing that it offered a pivot or 'heartland' region that was invulnerable to naval power and hence provided a base from which global dominance could be asserted. If the Eurasian landmass came under the control of a single power, then the Oceanic realms would inevitably be weaker in resources and military capabilities and global domination by the 'world island' would be possible. Subsequently Nicholas Spykman (1942) modified Mackinder's argument suggesting that the Eurasian littoral, what he called the Rimlands, was the key to world power. Ensuring that no power dominated this region and its population and resources was, he argued, key to ensuring that world politics avoided the dominance of a single power. Subsequently these concerns were loosely incorporated into various versions of the American containment strategies of the cold war period.

In partial contrast the American military historian Alfred Thayer Mahan (1890) emphasized the importance of naval power in the success of states in international rivalry suggesting that trading states that could control sea communication would thrive as a result of commerce while landlocked states without access to the sea were at a disadvantage. But geography suggests that there are some key "chokepoints" on the "sea lanes of communication" (SLOC), and military control of these can be very important. Keeping the Straits of Hormuz and the Straits of Malacca open continues to be a matter of great concern for American naval planners to ensure that oil tankers sail and that global commerce continues uninterrupted (Blair and Lieberthal 2007).

The Second World War had produced a whole new inventory of weapons and technologies that in some ways apparently rendered the geographical invulnerability of Mackinder's geographical pivot, or heartland, in central Asia outdated. Long range so called 'strategic' bombers carrying nuclear weapons could clearly range across Asia and attack bases or factories located there. Intercontinental ballistic missiles (ICBMs) armed with even more powerful hydrogen bombs and capable of flying many thousands of miles apparently confirmed the irrelevance of geographical factors in strategic thinking. At least they did so for a while in the 1950s and 1960s in American thinking where the geographical factors were less important than game theoretic calculations of likely scenarios for nuclear conflict. 
With both the Americans and Soviets apparently capable of mutually destroying each other's societies and war making capabilities by the late 1960s, a state of mutually assured destruction (MAD) then apparently applied and geography was supposedly effectively irrelevant to nuclear strategy. But it wasn't irrelevant to political influence and the supposed necessity to contain the spread of Soviet influence. The American intervention in Vietnam was justified in terms of preventing the fall of a dangerous 'domino' in the Rimlands to what was portrayed, despite the earlier Sino-Soviet split, as a global communist expansion. But the military forces the U.S. used were constrained both by political calculations and the inappropriate forces and equipment available for a sustained tropical counter insurgency campaign.

In the 1970s, with the practical deadlock between the superpowers as a result of the MAD standoff, classical geopolitics once again re-emerged in strategic thinking. Colin Gray (1977) led the way arguing that because of the nuclear deadlock, control over territory and resources once again mattered in international power struggles. Effectively the heartland was once again invulnerable because American nuclear weapons couldn't be used due to MAD. Hence, Gray argued, the verities of Mackinder and Spykman mattered once more and American military planners needed to think about their strategies in these terms.

He subsequently outlined a sophisticated argument for a nuclear theory of victory for nuclear planners in the West based in part on these ideas (Gray 1979). But one of the key overlooked parts of his analysis in the 1970s and early 1980s debates about nuclear weapons was how he extended his geopolitical analysis to interpret the structure of Soviet power in geographical terms (Dalby 1990). Gray's argument was that the Soviet system had inherited an imperial structure of rule with the peripheral parts only loosely integrated into the Russian/Soviet state. Thus, he argued, it was possible to devise a plausible set of war targets that would effectively paralyze the Soviet command structure by destroying key links in this highly centralized arrangement hence preventing it controlling the peripheries of its empire. He further argued that this could be done in a way that the Soviet Union couldn't counter effectively and hence the Soviet Union would be deterred from attempting to completely dominate Mackinder's world island.

Gray's reinvention of nuclear strategy depended in part on his insistence on putting the geographical dimensions of classical geopolitics and strategic thinking back into the discussion and linking it up with Clausewitz's thinking about war as the extension of politics. Thus strategy was about a clear political end; forces should be constructed to give politicians options in a crisis, options that in the case of the cold war were designed to make sure that nothing the Soviet Union did would prevent the United States from acting. But to make these strategies plausible required weapons that were accurate enough to target Soviet nuclear facilities and communications links. Accurate counterforce weapons rather than the less accurate countervalue city busters of the MAD era in the 1960s were needed.

\section{INNOVATION AND “ASTROPOLITICS”}


With enough of these accurate weapons in place, and the Trident and Pershing II missile systems, air launched cruise missiles, and mobile MX ICBMs were designed with such accuracy in mind that it might be possible to launch a plausible first strike on the Soviet Union. The 1980s forward deployed maritime strategy of hunting down and sinking Soviet ballistic missile submarines to remove that part of their deterrent forces was part of this thinking. All of which would, of course, be much assisted by effective anti-ballistic missile (ABM) systems to deny the Soviet Union the capability of launching its few remaining missiles in a retaliatory second strike. This compellance capability would then ensure that the Soviet Union was deterred in all plausible circumstances. While Ronald Reagan's strategic defense initiative (SDI) was justified in terms of its providing a missile shield to protect the United States, strategists understood that if it ever worked it would only do so against a limited retaliatory strike.

But both the putative plans for an SDI system and for first strike capable counter force weapons required huge advances in electronics, both in terms of computational power, navigation, sensors, and communications capabilities. Surveillance and coordination were at the heart of such technical innovations; both were required to monitor the huge spaces of the globe over which such a nuclear war would be fought. Survivability and redundancy were key and technologies which subsequently became commonplace in the internet had their origins in these strategic innovations. Thus the links between strategy in the cold war and the contemporary RMA are quite direct. American decisions in the 1970s to emphasize these technological advantages in command, control, intelligence, and coordination on the battlefield, as well as such things as 'stealth' aircraft, fit with these strategic innovations (Sloan 2002). Once the American draft was abolished in the 1970s a smaller professional military would also clearly need technological superiority to cope with Soviet conventional forces in Europe and elsewhere.

The RMA promised to deliver this superiority and did so in particular with aerial weapons and targeting. Guidance systems designed for nuclear cruise missiles to fight the Soviet Union are not that different from those subsequently used to deliver non-nuclear explosives to government facilities in Belgrade or Baghdad in the 1990s, or destroy buildings in villages in remote parts of Somalia in 2008 in hopes of killing Al Qaeda members. Likewise strategies designed to compel the Soviet rulers to accede to American policy by using precise targeting to cut key command links in their system are not so very different from those designed to disrupt Milosevic's or Hussein's control of their forces. But the land based military forces designed in the 1980s to fight a conventional tank battle war in Europe were not so easily adapted to fight the new wars of the 1990s (McGregor 1997) and now the war on terror. Nonetheless the assumptions that communications technology and surveillance systems would allow battle space dominance were key to many parts of the airland battle doctrinal innovations of the US forces in the 1980s.

Navigation and coordination of forces, especially in deserts and on oceans, is tremendously facilitated by reliable global positioning systems and the growing use of space based surveillance and communications. Targeting 'smart bombs' likewise, satellite photography allows for frequent monitoring of targets and the 
potential to switch surveillance rapidly without moving land based forces. The ability of American commanders to control drones and unmanned vehicles operating in Afghanistan and Iraq from bases in the United States both allows for ease of control and safety for operators distant from combat zones. All this is made possible by space based communication satellites. But this in turn makes American forces, dependent on their superior coordination and their ability to react faster than opponents on the battlefield because they can see what's going on better, vulnerable to the disruption of this infrastructure, in particular in space where so many communications satellites and monitoring systems are now situated.

Here too updated geopolitical thinking, sometimes referred to as 'Astropolitics,' has investigated the problems of controlling key parts of the 'new high ground,' and the chokepoints which are effectively key orbits in outer space (Dolman 2002). But as the anti-satellite weapon test the Chinese undertook in early 2007 suggests very clearly, this American infrastructure of communication is at least potentially vulnerable to disruption by relatively cheap countermeasures. Dominating near earth orbit is a preoccupation of space war thinkers; the assumption that it conveys considerable strategic advantage is a powerful one if one also assumes that state rivalries for world power are such that other states have an active interest in challenging the American presence there, and once established in space would actively seek to render satellites vulnerable. At least in a struggle with Al Qaeda or a military campaign in Iran or Korea, these space systems are not yet in danger; but in a major war they clearly would be.

\section{GLOBAL WARFARE}

In the aftermath of the cold war, the collapse of the Soviet Union, the disappearance of much of its military capability, and declarations by George Bush senior of a new world order, American military planners began to think about the new situation and what might be done with American dominance. The Gulf war in 1991 was to a very substantial extent an old fashioned air and tank war, but one where the new technologies were field tested apparently with great success. Although most of the munitions used in 1991 weren't 'smart,' the war story became one of the success of these bombs which apparently allowed allied victory with minimal casualties against a clearly outclassed foe (Beier 2006). The logistical effort to assemble the army in the desert had also clearly suggested the capabilities for American force projection across the region. 
The potential to use this superiority to assert American dominance round the globe, to prevent future challenges to American dominance even emerging became a key theme in what subsequently emerged as the neo-conservative view of the appropriate place of American power in the post cold war world (Dalby 2006). Geopolitics had morphed from a concern with European battlefields and nuclear standoff with the Soviets into a more general concern with maintaining American global dominance. Technological superiority should allow American forces to intervene anywhere at relatively short notice. But the shambles in Mogadishu in 1993 took the lustre off assumptions that firepower and technological superiority was enough to ensure effective policing of the world's trouble spots. Nonetheless American military force was soon again used in the Balkans, and repeatedly to degrade Iraqi military capabilities in the 1990s.

Then came the events of September 11th 2001 when an unanticipated attack by Al Qaeda suicide flyers challenged the geopolitical premises of American thinking fundamentally. The focus in neo-conservative thinking in the 1990s had been on states, not international terror operations as the primary focus of danger to American dominance (Kagan and Kristol 2000). Afghanistan immediately became the locus for military action in an arena for which there were few plans. The combination of airpower and money to buy the loyalty of local warlords fairly quickly removed the Taliban regime but failed to either capture or kill key Al Qaeda operatives. The capabilities of special forces and guided bombs suddenly suggested that the RMA had indeed fundamentally changed warfare, and simultaneously that the cold war geography of conflict was irrelevant (Rumsfeld 2002).

But quite why, when a few dissident Saudi Arabians and their Egyptian helpers hijacked some airliners in the United States, and crashed them into the World Trade Center and the Pentagon, this necessarily required a 'global war' response was very far from clear (Dalby 2003). One spectacular violation of American sovereignty turned the whole globe explicitly into a combat zone in the updated map of American combatant commanders areas of responsibility (Dalby 2007a). New national security doctrine statements and defense strategy statements have subsequently emphasized the global reach of American forces and the apparent necessity to build new ever more capable weapons systems and new bases in many parts of the world to facilitate the rapid movement of forces to new zones of conflict. This new geopolitical specification of global dangers provides the rationale for these new forces, weapons, and basing arrangements.

\section{THE 2006 QUADRENNIAL DEFENSE REVIEW}

The long awaited February 2006 Quadrennial Defense Review Report (QDR), providing the basis for longterm federal budget planning for the American Department of Defense, spells out these new geopolitical circumstances. Much of the strategic argument in the report built on the previous year's Defense Strategy of the United States 2005 document. But the QDR does have a clear geopolitical vision and a plan to remake the American armed forces in line with Rumsfeld's (2002) ideas of transformation. It emphasizes a wartime situation, one in which the United States is waging a 'long war' against terrorism. The forces needed to fight this war have to be planned and built along appropriate lines to ensure that the US prevails. 
Obviously engaging insurgents in Iraq or Al Qaeda operatives in Yemen or Afghanistan requires a very different military from that required to fight Soviet tank divisions in Europe. But how different depends to a large extent on how that arena of combat is understood; how, in short, the geopolitical imagination of American strategists specifies, once again, the arena in which the country will be militarily engaged.

Throughout much of its history, the United States enjoyed a geographic position of strategic insularity. The oceans and uncontested borders permitted rapid economic growth and allowed the United States to spend little at home to defend against foreign threats. The advent of long-range bombers and missiles, nuclear weapons, and more recently of terrorist groups with global reach, fundamentally changed the relationship between U.S. geography and security. Geographic insularity no longer confers security for the country. (QDR 2006: 24)

The QDR emphasizes the transformation from a peace-time military prepared to engage an enemy if necessary to a battle-hardened and tested fighting entity constantly learning new lessons from the field and transforming into a much more agile force. It outlines four priorities for the next few years: defeating terrorist networks; defending the homeland in depth; shaping the choices of countries at strategic crossroads; and preventing hostile states and non-state actors from acquiring or using weapons of mass destruction. Not all of these priorities suggest combat operations. The third priority clearly refers to diplomatic and political action to prevent states from taking stances in opposition to American interests, ensuring that states are "with us” not “with the terrorists,” following President George W. Bush's rhetoric in the aftermath of September 11th 2001 (Bush 2001). Shaping the political environment rather than waiting for hostile forces to emerge is crucial to strategy in the global war on terror.

This geopolitical specification of the world is however complemented by one in which a layered defense of the homeland of the USA is at the heart of these new structures. Hence homeland defense gets priority, and the revived plans for missile defense are part of this protection of the continental United States. Beyond this is a series of layered zones of decreasing importance. Ensuring the inviolate spatial protection of the homeland is the lynchpin to all this, security of the base of operations is the first priority because only with that accomplished can American forces undertake their expeditions abroad. The 2006 National Security Strategy of the United States statement makes it clear that these will probably be required in support of the overarching national security objective of the United States which is now nothing less than ending tyranny on earth. Rather than containing the Soviet Union, a strategy of preventing the expansion of a hostile power, the new geopolitical specifications now suggests an offensive strategy to remove dangerous regimes and expand the remit of liberty understood in terms of liberal economies, international trade arrangements, and at least some bilateral cooperation agreements between the United States and other regimes. The apparent success of the weapons provided by the RMA in changing regimes in Belgrade, Baghdad, and Kabul supposedly suggests the potential utility of these forces in this new geopolitical situation. 
The current reorganization of military bases around the world is understood as a move from Cold War garrisons to a posture designed for the rapid launching of expeditionary forces. The reorganization of the army in particular into smaller brigade-sized units is designed to facilitate rapid deployment 'surges' into 'trouble spots.' Joint operations between the various services are given priority in contrast to the previous separation of tasks and roles. New and asymmetric threats are the focus rather than earlier assumptions of near peer competition with rising states. Insofar as there is a guide to fighting this new war, the author given pride of place is T. E. Lawrence (of Arabia), whose attack on Ottoman-held Aqaba during the First World War is cited as the kind of indirect surprise assault that the United States is planning to use against Al Qaeda and other networks of terrorists (Lawrence 1935; see also Barnett 2006).

This is clearly a global war, one in which American troops are dispersed around the world to carry out a huge number of assignments, from training to intelligence-gathering. More specifically, “[o]n any given day, nearly 350,000 men and women of the U.S. Armed Forces are deployed or stationed in approximately 130 countries. They are battle-hardened from operations over the past four years, fighting the enemies of freedom as part of this long war"(QDR 2006: 9). But they are also involved in disaster relief, in the aftermath of the Indian Ocean Tsunami in late 2004, the earthquake in Pakistan in late 2005, and various other emergency situations. Intervention in Liberia in 2003 is also mentioned in the QDR, as are drug interdictions in Columbia and numerous other operations, many by small liaison and training teams who rarely garner any media attention. The U.S. military is thus proud of its earth-spanning presence, with troops in two-thirds of the sovereign states on the planet.

However, given the acknowledged global scope of the U.S. armed forces, and the expressed desire to remake distant societies so as to stifle the emergence of threats to the metropolitan centre, it is not much of a stretch to argue that imperial pacification is the mandate of the war on terror, and that a debate over the semantics of empire is unnecessary (Johnston 2007; Kaplan 2005, 2007). As the QDR's (2006: 21-22) authors put it:

Victory will come when the enemy's extremist ideologies are discredited in the eyes of their host populations and tacit supporters, becoming unfashionable, and following other discredited creeds, such as Communism and Nazism, into oblivion. This requires the creation of a global environment inhospitable to terrorism. It requires legitimate governments with the capacity to police themselves and to deny terrorists the sanctuary and the resources they need to survive. It also will require support for the establishment of effective representative civil societies around the world, since the appeal of freedom is the best long-term counter to the ideology of the extremists.

This sweeping declaration, also present (in similar form) in the paradigmatic 2002 National Security Strategy of the United States, and in the 2006 update, not only reprises the ideological character of the Cold War, but equally gestures to the Clinton administration's foreign policy of 'enlargement' of the area ruled by democratic states. 
Even so, the military globalism of the war on terror is predicated on a fundamental change in the specification of America's place in the world. The homeland must be defended in depth because globalization has rendered it insecure. While acknowledging the many economic benefits of globalization, the QDR goes on to argue that "it is also accelerating the transmission of disease, the transfer of advanced weapons, the spread of extremist ideologies, the movement of terrorists, and the vulnerability of major economic segments” (QDR 2006:24). The complexity and speed of these threats, again, requires pre-emptive forms of strategy, particularly in the form of constant surveillance and international collaboration. A long list of possibilities and contingencies follows, outlining ways in which states and extremists might launch attacks on America to cause catastrophic damage.

But why the United States might be a target is not seriously considered; its given geopolitical status as endangered is just that: a given, for the Department of Defense. This insistence on the fundamental virtue of the United States is the corollary of the long war; if the US is endangered it has to be due to some external cause. Such causes justify the transformation of that external environment, by force if necessary; and new mobile expeditionary forces designed to "shape the future" rather than respond to threatening contingencies are outlined in the QDR. But the QDR explicitly states that the expeditionary forces will be based mostly in the United States but be 'surged' rapidly to wherever they are needed round the globe; clearly threats are now understood in a geopolitical specification of the whole planet as a potential battle space. Strategic lift capacities will be combined with these new bases to ensure rapid deployment anywhere in the globe that American forces are needed in the new global arena of conflict. No longer will regional commands 'own' the forces assigned to their theatre of operations; they instead will provide the command structure while the logistical tasks of surging forces will be conducted at a global scale. Here the RMA meets the new geopolitical arrangements for conducting war anytime anywhere.

It is all too easy to emphasize novelty in the QDR document, and to suggest that the transformation of the American military is moving ahead rapidly as a result of a new geopolitical vision. But as critics of the QDR were very quick to point out, many major weapons programs of the past are proceeding apace with no apparent compelling new missions in the immediate war on terror (Kaplan 2006; Conetta 2006). More flexible army units and expanded unmanned aircraft drones are prioritized, but so too are new submarines, carriers, and over 2000 joint strike fighters. According to the QDR there is an American military presence in some 130 states, as well as an unchallenged Navy, Air Force, and a global surveillance system, all of which suggests that American power is understood as a global presence; geopolitics is now about the administration of much of the globe; Spykman's Rimlands in particular. But it is now also about taking the war to various putative enemies and using preemption if necessary to remove regimes deemed threatening. Replacing them with states that are active participants in the international regime of American lead economic liberty is key to this struggle to eliminate tyranny as both the 2002 and 2006 versions of the National Security Strategy make clear.

\section{SHAPING THE FUTURE}


The most explicit popular representation of this new strategy of removing threats and shaping the future, and the argument for new forces needed to make it effective, is probably in popular author, pundit, blogger (www.thomasbarnett.com) and Pentagon consultant, Thomas Barnett's books, The Pentagon's New Map (2004) and Blueprint for Action (2005). What is interesting about these representations of geopolitics is not only Barnett's explicit use of one key cartographic aid in dividing the world into a developed integrated core economy region, and a non-integrated gap in need of, if necessary, forcible integration into the global economy, but also his direct connection of this geopolitical understanding to the debate about force transformation. He explicitly argues that not only does America need to have an overwhelming preponderance of force available, a 'Leviathan force,' to remove recalcitrant regimes, but it also needs what he calls a system administration force designed to rebuild economies and societies after the local dictators are gone. He argues that this is what is needed to ensure that the wild and dangerous zones in the non-integrated gap, where terrorists and criminals plot their evil plans, do not revert to their threatening activities, is a combination of peacebuilding, development, and civil administrators who can teach a presumably grateful local population the ways of the Western world so they too can take advantages of the benefits of being plugged into the global economy.

He contrasts this vision with a very prevalent one in American geopolitical thinking, one focused on great powers and the assumption that history shows that one will inevitably arise to challenge American leadership (see Grygiel 2006). In particular Barnett challenges the geopolitical assumption that great powers are still relevant as actors on the world stage. Neither is he interested in world islands, nor the traditional geopolitical theme of the rivalry of sea and land powers. Instead he posits a world divided into a zone of prosperity threatened by the non-integrated gap. Arguing that China would prefer to trade than fight, he suggests a grand alliance of globalizing powers to finally subdue the recalcitrant peripheries; final victory for civilization is possible if only the forces of global modernity recognize their common interest in removing the remaining rogue states and their sanctuaries for terrorists, criminals, and other threats to global prosperity. Such a contrast of geopolitical perspectives throws the discussion of the RMA into sharp relief by posing the key questions of grand strategy at the heart of this geopolitics and asking how the world is specified so as to require these forms of military conduct. Barnett also explicitly suggests the possibility of a final victory in 'the long war' when the gap has finally been integrated, in contrast to the realist pessimism of inevitable interminable great power rivalries.

What has been so painfully revealed by the relative neglect of Afghanistan and the lack of any clear plan to administer Iraq after the 2003 invasion, is the limitations of the RMA in terms of its abilities to accomplish practical tasks of reconstruction and pacification in the aftermath of its combat successes (Ricks 2006). Clearly the American forces have gained much in terms of combat power by the adoption of the new technologies and their ability to relatively effortlessly remove weak and marginal military forces in both Iraq and Afghanistan. But Barnett's criticism is precisely that while this may be necessary, it is not sufficient for the current geopolitical circumstances. This is not the only kind of military capability that the United States 
needs in the situations it faces. The RMA was about technology designed to defeat conventional armies. It is tied to a geopolitical vision of a world of competing states, and specifically of competing great powers in a rivalry for global power and influence.

After the disaster in Vietnam where the army disgraced itself in a war it could not win, and the Air Force used excessive violence to no obvious strategic purpose, the officer corps decided to abandon counter-insurgency operations and training and focus on the rebuilding of the forces to defeat what they understood as the main potential enemy of the time, the Soviet forces in Europe. In focusing on other states, and the importance of major combat operations, the other function of militaries through the ages, that of occupation, administration, and enforcement of rule on reluctant populations, has been largely abandoned (Ricks 2006). Now in Iraq and Afghanistan the American military has been forced to dust off the old lessons of counter-insurgency and reinvent the doctrines and tactics that it stopped teaching and training for in the 1970s.

The focus on military operations as they merge into criminality and policing, and propaganda and media strategies, and do so in ill-defined terrains where national borders seem to count for little suggests that the precise geographies of the conflict are not clear, and boundaries and borders are much less important than they used to be when geopolitics was about superpower blocs. Mary Kaldor (2007) talks about this in terms of what she calls "organized violence" in a global era. Diasporic urban populations support nationalist movements 'back' in the homeland. Resources controlled by rebels are sold on the international commodity markets to raise weapons to fight what are not strictly speaking 'civil' wars. Criminality and militias merge as struggles over local economies and the loyalty of populations take precedence over fights for territory. This is the new geography of violence in the 'new wars' of the twenty first century, a violence which the RMA has not equipped Western forces to fight effectively over the long term.

\section{FUTURE GEOPOLITICAL THREATS?}

Through 2007 there was much discussion of the possibilities of an American or Israeli attack on Iran, ostensibly to prevent the emergence of a nuclear weapons capable Iranian state. While there has been endless speculation about its likelihood, and much expression of alarm at the folly of extending the war in the Middle East, there has been much less discussion of the strategic logic of an attack on Tehran. In terms of the 2006 National Security Strategy, and the 2006 QDR in particular, it is clear that such an attack is entirely consistent with the logic of the Bush doctrine. Removing regimes that might potentially provide weapons of mass destruction to terrorists or use them directly against American forces is what the doctrine states is its major priority on the road to victory. Iran would thus seem to be the next state in line to be attacked.

If it happens, an air assault on Iran using the latest smart weapons to disable the Iranian military and at least some of its nuclear capabilities, is entirely within the parameters of the doctrine. But its goal would clearly be regime change as part of the strategy to end tyranny. Given the limited ground troops likely to be available the model would appear to be Serbia in 1999 where a major air assault on the state's infrastructure had the 
eventual political effect of removing Milosevic from power. Sanctions and political pressure in addition to the practical disruption of economic life made the regime untenable in the medium term. While the initial assault on the Iranian military and revolutionary guards would no doubt foster nationalist support for the regime, the strategy would presumably look to short or medium term political destabilization to deal with the Mullahs who would hopefully, from the American viewpoint, be incapable of providing basic needs in the aftermath of the American assault. But such calculations do require that the Iranian threats to retaliate against oil infrastructure and shipping in the Gulf are discounted as likely to be ineffective (Blair and Lieberthal 2007). What North Korea might do in such a crisis, given that it would then certainly expect to be the next, or perhaps next after Syria to be attacked, rarely gets a mention.

An American assault on Iran, should it transpire, also requires that the rest of the world at least acquiesce to this military action and that such an attack does not set in motion political trends that work to constrain the future possibilities for American unilateral actions. Here the logic of the doctrine runs into political difficulties if the international community becomes convinced that America is operating, not as the sheriff in Colin Gray's phrase (2004), policing a basically benign world order, but as an aggressive and self interested power acting to maintain its dominance. Key to all this is whether the rest of the world shares a basic understanding of the geopolitical map with the United States, and whether even if they do, they have, after Afghanistan and Iraq, any confidence that the strategy of regime change will succeed. If key players don't accept the basic premise of ending tyranny, shrinking the gap, and periodically using force to do so in the name of expanding economic liberty qua globalization, then the possibilities for the long war precipitating a further reshaping of geopolitical matters looms.

If international institutions are once again ignored in a unilateral operation then the possibilities for great power rivalry emerging and once again redrawing geopolitical lines of confrontation are considerable. Military buildups, strategic forces designed to fight wars that do not provide the American high tech weapons with target sets, and alliances on the Eurasian continent to challenge the American presence in South West Asia are all possibilities. Such arrangements might be accelerated if Iranian resistance to American attacks included destruction of petroleum infrastructure in the Gulf and enough destabilization there to disrupt oil flows long enough to precipitate a substantial global economic recession. Such a crisis would no doubt be used as a powerful political argument for the continued militarization of American foreign policy, fulfilling the worst fears of those who see current events in imperial terms, and as the end of the American republic (Bacevich 2005; Johnston 2007). The international repercussions would be very considerable but are impossible to predict.

In 2007 further doubt was cast on the appropriateness of the military capabilities of the current RMA for dealing with future security challenges, and the appropriateness of the geopolitical specification of the world that underlies the Bush doctrine. The discussion of climate change and the possible disruptions to many societies in the near future has once again come to prominence in policy making circles; little in the RMA 
is much help in dealing with such threats which emanate from, in Thomas Barnett's terms, the core rather than from the gap. While military planners are now beginning to wonder what kind of threats climate disruptions may present and how they might better prepare, equip, and train to deal with disasters, forced migration, and other disruptions (CNA Corporation 2007; Centre for Strategic and International Studies 2007), clearly a fossil fueled global military is part of the cause of such disruptions.

While surveillance systems and mobile forces have considerable potential for dealing with these difficulties, once again the key question of the geopolitical assumptions made by political and military planners will be important. Building forces to deal with emergencies but not direct military threats, is not what the recent military revolution has been about, but military operations other than war are clearly part of what armed forces do currently. If climate change sets migration in motion on a large scale, then all sorts of more serious problems may require military attention (Smith 2007), but preventing climate disaster and preparing societies for the coming changes, is not something that the current revolution in military affairs equips contemporary states to do. Numerous space based technologies may have some uses in monitoring environmental changes or facilitating communications in dealing with disasters, but they are not much use in reducing the human disruptions of ecosystems. The overtly military response to the war on terror, and the geopolitical formulation of security primarily in terms of regimes judged unfriendly to the American world order, diverts attention from these other pressing policy necessities for the future, not least by precluding more cooperative ventures in many places.

Which ironically brings us back to the first revolution in military affairs mentioned at the beginning of this paper. While Alexander had the military capability of defeating all foes he faced in the ancient world he was powerless to prevent the destruction of most of his army in the extreme environment of the desert dry lands of what is now Iran. Geographical factors can no more be ignored today as they could have been then. Understanding the environment and planning appropriately for how to encounter the future remains essential to security; thinking carefully about the appropriate geopolitical specifications is the unavoidable first step. If as Paul Rogers (2008) suggests, we have little choice but to think about security in sustainable terms in the future, then rethinking contemporary geopolitical premises must be part of the process. Climate change challenges contemporary formulations quite profoundly; geopolitical maps that place humanity within a small biosphere that we are disrupting (Dalby 2007b), rather than on a planetary surface that Americans and their friends are trying to control with precision guided weapons, will be an essential part of any such reconfiguration of security priorities after the Bush doctrine has finally run its course.

\section{NOTE}

An earlier draft of part of this paper appears as "Geopolitik und die Transformation der Streitkräfte” in Jan Helmig und Niklas Schörnig (2008) Die Transformation der Streitkräfte im 21. Jahrhundert. Militärische und Politische Dimensionen, Frankfurt Am Main: Campus. 
Dalby $\nleftarrow$ Geopolitics, the Revolution in Military Affairs, and the Bush Doctrine / 15 
Dalby $\checkmark$ Geopolitics, the Revolution in Military Affairs, and the Bush Doctrine / 16

\section{Works Cited}

Agnew, J. (2003). Geopolitics: Revisioning World Politics. London: Routledge.

Bacevich, A. (2005). The New American Militarism: How Americans Are Seduced by War. Oxford: Oxford University Press.

Barnett, T. P. M. (2004). The Pentagon's New Map: War and Peace in the Twenty-first Century. New York: Putnam's.

—. (2005). Blueprint for Action: A Future Worth Creating. New York: Putnam’s.

—. (2006). “The Monks of War.” Esquire (March): 214-219, 234-237.

Beier, J. M. (2006). “Outsmarting Technologies: Rhetoric, Revolutions in Military Affairs and the Social Depth of Warfare.” International Politics 43: 266-280.

Blair, D. and Lieberthal, K. (2007). “Smooth Sailing.” Foreign Affairs 86(3): 7-13.

Boot, M. (2006). War Made New: Technology, Warfare, and the Course of History 1500 to Today. New York: Gotham.

Bush, G. W. (2001). “Address to a Joint Session of Congress and the American People.” 20 September. Last retrieved from <http://www.whitehouse.gov/news/releases/2001/09/20010920-8.html>.

—. (2004). "President Bush Calls for Renewing the USA PATRIOT Act." 19 April. Last retrieved from <http://www.whitehouse.gov/news/releases/2004/04/20040419-4.html>.

Center for Strategic and International Studies. (2007). The Age of Consequences: The Foreign Policy and National Security Implications of Climate Change. Washington: Center for Strategic and International Studies.

CNA Corporation. (2007). National Security and the Threat of Climate Change. Alexandria: CNA Corporation. Last retrieved from <www.securityandclimate.cna.org $>$.

Conetta, C. (2006). “QDR 2006: Do the Forces Match the Missions? DOD Gives Little Reason to Believe.” Project on Defense Alternatives Briefing Memo \#36. 10 February. Last retrieved from $<$ http://www.comw.org/pda/0602bm36.html>.

Dalby, S. (1990). Creating the Second Cold War: The Discourse of Politics. London: Pinter and New York: Guilford.

—. (2003). “Calling 911: Geopolitics, Security, and America’s New War.” Geopolitics 8(3): 61-86.

— (2006). "Geopolitics, Grand Strategy, and the Bush Doctrine: The Strategic Dimensions of U.S. Hegemony under George W. Bush” in C. P. David and D. Grondin (eds.), Hegemony or Empire? The Redefinition of American Power under George W. Bush. Aldershot: Ashgate. 33-49. 
Dalby Geopolitics, the Revolution in Military Affairs, and the Bush Doctrine / 17

—. (2007a). "Regions, Strategies, and Empire in the Global War on Terror.” Geopolitics 12(4): 586606.

— (2007b). “Ecology, Security, and Change in the Anthropocene.” Brown Journal of World Affairs 13(2): 155-164.

(2005). Defense Strategy of the United States of America. March. Washington: Department of Defense.

Dolman, E. C. (2002). Astropolitik: Classical Geopolitics in the Space Age. London: Frank Cass.

Gray, C. S. (1977). The Geopolitics of the Nuclear Era: Heartlands, Rimlands, and the Technological Revolution. New York: Crane, Russack \& Co.

. (1979). “Nuclear Strategy: The Case for a Theory of Victory.” International Security 4(1): 5487.

— (2004). The Sherriff: America's Defense of the New World Order. Lexington: University of Kentucky Press.

Grygiel, J. J. (2006). Great Powers and Geopolitical Change. Baltimore: The Johns Hopkins University Press.

Johnston, C. (2007). Nemesis: The Last Days of the American Republic. New York: Metropolitan.

Kagan, R. and Kristol, W. (2000). Present Dangers: Crisis and Opportunity in American Foreign and Defense Policy. San Francisco: Encounter.

Kaldor, M. (2007). New and Old Wars. $2^{\text {nd }}$ Edition. Stanford: Stanford University Press.

Kaplan, F. (2006). "Rumsfeld Surrenders: The QDR Dashes his Dreams of Military Transformation.” Slate, 3 February. Last retrieved from <http://www.slate.com/id/2135343/>.

Kaplan, R. (2005). Imperial Grunts: The American Military on the Ground. New York: Random House.

- (2007). Hogpilots, Blue Water Grunts: The American Military in the Air, Sea and on the Ground. New York: Random House.

Lawrence, T. E. (1935). The Seven Pillars of Wisdom. London: Cape.

Macgregor, D. A. (1997). Breaking the Phalanx: A New Design for Landpower in the $21^{\text {st }}$ Century. Westport: Praeger.

Mackinder, H. J. (1904). “The Geographical Pivot of History.” The Geographical Journal 23: 421-437.

Mahan, A. T. (1890). The Influence of Seapower on History. Boston: Little Brown.

(2002). National Security Strategy of the United States of America. February. Washington: The White House. 
Dalby $\checkmark$ Geopolitics, the Revolution in Military Affairs, and the Bush Doctrine / 18

(2006). National Security Strategy of the United States of America. February. Washington: The White House.

(2006). Quadrennial Defense Review Report. February. Washington: Department of Defense.

Ricks, T. E. (2006). Fiasco: The American Military Adventure in Iraq. New York: Penguin.

Rogers, P. (2008). Why We're Losing the War on Terror. Cambridge: Polity.

Rumsfeld, D. H. (2002). “Transforming the Military.” Foreign Affairs 81(3): 20-32.

Sloan, E. (2002). The Revolution in Military Affairs. Montreal and Kingston: McGill-Queens University Press.

Smith, P. J. (2007). “Climate Change, Mass Migration and the Military Response.” Orbis 51(4): 617633.

Spykman, N. (1942). America’s Strategy in World Politics. New York: Harcourt Brace.

\section{BIOGRAPHY}

Simon Dalby is Professor of Geography and Political Economy at Carleton University in Ottawa. He has a Ph.D. from Simon Fraser University. He is author of Creating the Second Cold War (Pinter and Guilford, 1990) and Environmental Security (University of Minnesota Press, 2002) and coeditor of Rethinking Geopolitics (Routledge, 1998) and The Geopolitics Reader (Routledge, 1998, 2006). 